\title{
KOLABORASI ANTARA APARATUR BIROKRASI PEMERINTAH DAERAH ISTIMEWA YOGYAKARTA DAN FORUM PENGURANGAN RISIKO BENCANA (FPRB) DIY DALAM PENYELENGGARAAN PENANGGULANGAN BENCANA DI DAERAH ISTIMEWA YOGYAKARTA
}

\author{
Dwi Agustina \\ Institut Ilmu Sosial dan Manajemen STIAMI \\ dwiagustina1808@gmail.com
}

\begin{abstract}
Abstrak. Daerah Istimewa Yogyakarta (DIY) dapat dikatakan sebagai laboratorium mini bencana, hal ini dikarenakan potensi terjadinya bencana di DIY sangat besar. DIY memiliki 12 ancaman bencana yaitu: Banjir, Epidemi \& Wabah penyakit, Gelombang Ekstrim \& Abrasi, Gempa Bumi, Tsunami, Gagal teknologi, Kekeringan, Letusan Gunung Api, angin Kencang,Tanah Longsor, Kebakaran, dan Bencana Sosial.

Dengan adanya beberapa Jenis ancaman Bencana tersebut tentunya menjadi tantangan tersendiri bagi Pemerintah Daerah Istimewa Yogyakarta. Pemerintah dituntut lebih siap dalam menurunkan risiko jumlah korban apabila terjadi bencana. Penyelenggaraan penanggulangan bencana tidakklah dapat dilakukan oleh satu pihak saja, sesuai dengan amanat Undang-Undang No 24 Tahun 2007 yang menyatakan bahwa penyelenggaraan Penanggulangan bencana pemerintah tidak boleh melakukan sendirian dan harus melibatkan multi stakeholder.

Pada penelitian ini menggunakan metode penelitian Kualitatif Deskriptif, dengan teknik pengumpulan data melalui Observasi langsung, Wawancara mendalam dengan Pemeriintah Daerah Istimewa Yogyakarta, BPBD, dan beberapa anggota Forum PRB Yogyakarta. dan Penelaahan terhadap Dokumentasi tertulis.

Pemerintah Daerah Yogyakarta menyadari bahwa pelibatan multi stakeholder diperlukan dalam penyelenggaraan penanggulangan bencana. atas dasar inisiasi dari berbagai stakeholder yang terlibat dalam pelaksanaan penanggulangan bencana pada saat gempa bantul maka dibentuklah sebuah forum sebagai wadah berkumpulnya para stakeholder dari berbagai unsur yaitu Forum Pengurangan Risiko Bencana atau lebih sering disebut Forum PRB DIY. Dengan adanya froum ini para aktor melakukan fungsi masing-masing dengan cara berkoordinasi dan saling bekerjasama.

Penelitian ini yang mengacu pada kolaborasi antara Pemerintah DIY dan Forum PRB DIY mendapatkan hasil bahwa pelaksanaan penyelanggaraan Penanggulangan bencana di DIY saat ini telah dilakukan oleh berbagai multi aktor secara kolaboratif. Masing-masing aktor telah di bagibagi perannya sesuai dengan keahlian masing-masing. Dalam Collaborative Governance dapat dilihat melalui dua Dimensi yaitu Sistem Konteks dan dimensi pendorong. Melalui dua dimensi tersebut dalam penelitian ini melihat bagaimana kolaborasi yang terjadi diantara Pemerintah DIY dan Froum PRB DIY.
\end{abstract}

Kata Kunci: Bencana, Penyelenggaraan penanggulangan bencana, Multi Stakeholder, Collaborative Governance

Abstract. Yogyakarta Special Region (DIY) can be regarded as a mini-disaster laboratory, this is because the potential for disaster in DIY is very big. DIY has 12 disaster threats: Flood, Epidemic \& Outbreak, Extreme \& Abrasion, Extreme \& Abrasion, Earthquake, Tsunami, Failure Technology, Drought, Volcano Eruption, High winds, Landslide, Fire and Social Disasters.

With the existence of several types of threats Disaster is certainly a challenge for the Government of Yogyakarta Special Region. The government is expected to be better prepared to reduce the risk of casualties in the event of a disaster. Implementation of disaster management can not be done by one party only, in accordance with the mandate of Act No. 24 of 2007 stating that the implementation of disaster management government should not do alone and must involve multi 
stakeholders.

This research uses descriptive qualitative research method, with data collecting technique through direct observation, in-depth interview with Pemeriintah Daerah Istimewa Yogyakarta, BPBD, and some members of PRB Yogyakarta Forum. and review of written documentation.

Local Government of Yogyakarta realized that multi-stakeholder involvement is needed in disaster management. on the basis of the initiation of various stakeholders involved in the implementation of disaster management during the earthquake bantul then formed a forum as a forum for gathering of stakeholders from various elements of the Forum Disaster Risk Reduction or more often called DIY DRR Forum. With this froum the actors perform their respective functions by coordinating and working together.

This study, which refers to the collaboration between the DIY Government and DIY DRR Forum, has resulted that the implementation of Disaster Management in Yogyakarta has now been done by various multi-actors collaboratively. Each actor has been divided into roles according to their respective expertise. In Collaborative Governance can be seen through two dimensions of the Context System and the driving dimension. Through these two dimensions in this study see how the collaboration between DIY Government and Froum DRR DIY.

Keywords: Disaster, Disaster Management, Multi Stakeholder, Collaborative Governance

\section{PENDAHULUAN}

Bencana merupakan proses dinamis hasil kerja ancaman (hazards) terhadap komponen ekonomi, politik, dan ekologis yang disebut kerentanan. Kerentanan berkaitan erat dengan kesenjangan (inequality) yang dihasilkan dari proses pembangunan, sehingga pembangunan wajib mengintegrasikan faktor bencana demi keberlanjutannya. Manajemen pembangunan berkelanjutan perlu mengandalkan kebijakan dan praktik pengurangan risiko bencana secara berkelanjutan.

Permasalahan penelitian merujuk pada pengalaman penanggulangan bencana yang diterapkan di berbagai daerah di Indonesia yang masih mengalami berbagai kendala, baik di tingkat pemerintah maupun masyarakat. Kendala di tingkat pemerintah terlihat pada lemahnya koordinasi antara pemerintah dan para pemangku kepentingan lainnya, baik dalam tahap pra bencana, pada saat terjadi bencana, maupun pada saat pasca bencana.

Peran pemerintah daerah dan para pemangku kepentingan lain dalam penanggulangan bencana yang belum optimal dipengaruhi oleh belum adanya landasan operasional penanggulangan bencana atau belum dipahami secara utuh dalam pelaksanaannya Hasil penelitian menunjukkan bahwa masyarakat memiliki peran yang maksimal dalam penanggulangan bencana dengan adanya dukungan penuh dari berbagai pihak terutama aparatur pemerintah. Namun demikian, belum dijumpai penelitian yang khusus melakukan penilaian terhadap kolaborasi antara pemerintah dan organisasi non pemerintah mendetail terkait kegiatan penanggulangan bencana, sehingga sangat penting untuk dilakukan.

Menyadari dengan Adanya berbagai permasalahan yang dialami Pemerintah daeerah dalam tahapan manajemen bencana, Pemerintah Daerah DIY berusaha melakukan Kolaborasi dengan pihak lain, sesuai dengan amanat UU No 24 Tahun 2007 tentang Penanggulangan bencana bahwa kegiatan penanggulangan bencana tidak hanya dlakukan oleh pemerintah saja. Maka dengan itu Pemerintah DIY berkolaborasi dengan Forum PRB DIY dalam upaya kegiatan pengurangan risiko bencana serta kegiatan penanggulangan bencana di DIY.

Forum Pengurangan Risiko Bencana Daerah Istimewa Yogyakarta (Forum PRB DIY) adalah Forum adalah wadah yang menyatukan organisasi pemangku kepentingan (multy stakeholders) DI.Yogyakarta yang bergerak dalam mendukung upaya-upaya pengurangan risiko 
Dwi Agustina, Kolaborasi Antara Aparatur Birokrasi Pemerintah Daerah Istimewa ...

bencana (PRB) di wilayah DI.Yogyakarta. Sebagai Platform Pengurangan Risiko Bencana di tingkat provinsi yang menyediakan mekanisme koordinasi untuk meningkatkan kolaborasi \& koordinasi berbagai pemangku kepentingan dalam keberlanjutan aktivitas-aktivitas PRB melalui proses konsultatif dan partisipatif yang selaras dengan pelaksanaan kerangka kerja PRB sebagaimana ditetapkan kebijakan nasional. Forum Pengurangan Risiko Bencana Daerah Istimewa Yogyakarta memberikan kontribusi dalam pengurangan risiko bencana melalui advokasi, pengawasan, fasilitasi dan konsultasi yang memungkinkan terjadinya pengarusutamaan pengurangan risiko bencana bagi semua pemangku kepentingan menuju komunitas yang tanggap dan tahan bencana. Bentuk kerjasama yang terkoordinasi dengan baik antar berbagai lembaga pemerintah dan non pemerintah dalam situasi kesiapsiaagaan dalam manajemen penanggulangan bencana tentu saja akan menentukan performa yang diberikan pada saat penanganan bencana.

Tantangan-tantangan yang muncul dalam proses penanganan korban bencana adalah bagaimana membangun keharmonisan dalam bekerjasama antar sektoral terkait yang terlibat dalam penanggulangan bencana. munculnya berbagai masalah pasca bencana, seperti banyaknya korban yang tidak memperoleh layanan kesehatan yang memadai, tidak meratanya bantuan logistik, banyaknya korban yang tidak terjangkau program bantuan, informasi yang tidak pasti,kebijakan yang berubah-ubah, dan seterusnya merupakan indikasi yang memperlihatkan bentuk kerjasama yang belum terkoordinasi secara optimal.

Berangkat dari beberapa peran yang dilakukan Forum PRB DIY dalam Penanggulangan Bencana serta beberapa program yang dilakukan bekerja sama dengan pemerintah yang menjadi bagian dari forum RPB ini maka penelitian ini ingin melihat Bagaimana Kolaborasi Antara Aparatur Pemerintah DIY Dan Forum PRB DIY Dalam Penanggulangan Bencana di Daerah Istimewa Yogyakarta.

\section{Kerangka Teoritik}

Secara umum dijelaskan bahwa collaborative governance merupakan sebuah proses yang di dalamnya melibatkan berbagai stakeholder yang terikat untuk mengusung kepentingan masing-masing instansi dalam mencapai tujuan bersama. Sedangkan Ansell dan Gash mendefinisikan Collaborative Governance sebagai Sebuah pengaturan yang mengatur satu atau lebih lembaga publik secara langsung terlibat dengan pemangku kepentingan non publik dalam proses pengambilan keputusan kolektif yang bersifat formal, berorientasi konsensus, dan musyawarah yang bertujuan untuk membuat atau mengimplementasikan kebijakan publik atau mengelola program atau asset publik. Definisi tersebut di atas dapat dirumuskan beberapa kata kunci yang menekankan pada enam karakteristik, antara lain:

1) Forum tersebut diinisiasi atau dilaksanakan oleh lembaga publik maupun aktor-aktor dalam lembaga publik.

2) Peserta di dalam forum tersebut juga termasuk aktor non publik.

3) Peserta terlibat secara langsung dalam pembuatan dan pengambilan keputusan dan keputusan tidak harus merujuk pada aktor-aktor publik.

4) Forum terorganisir secara formal dan pertemuan diadakan secara bersamasama.

5) Forum bertujuan untuk membuat keputusan atas kesepakatan bersama, dengan kata lain forum ini berorientasi pada konsensus.

6) Kolaborasi berfokus pada kebijakan publik maupun manajemen publik.

Definisi ini dapat dimaknai bahwa forum tersebut ada pada sebuah keterikatan formal sehingga disebutkan hanya berkisar pada kerjasama antara lembaga publik, aktor publik dengan aktor non-publik. Berbeda halnya dengan definisi collaborative governance yang dijelaskan Agrawal dan Lemos bahwa definisi collaborative governance tidak hanya berbatas pada stakeholder yang terdiri dari pemerintah dan non-pemerintah tetapi juga terbentuk atas 
adanya "multipartner governance" yang meliputi sektor privat, masyarakat dan komunitas sipil dan terbangun atas sinergi peran stakeholder dan penyusunan rencana yang bersifat hybrid seperti halnya kerjasama publik-privat dan privat-sosial. Definisi hampir serupa disampaikan oleh Balogh dkk (2011) dijelaskan bahwa collaborative governance merupakan sebuah proses dan struktur dalam manajemen dan perumusan keputusan kebijakan publik yang melibatkan aktor- aktor yang secara konstruktif berasal dari berbagai level, baik dalam tataran pemerintahan dan atau instansi publik, instansi swasta dan masyarakat sipil dalam rangka mencapai tujuan publik yang tidak dapat dicapai apabila dilaksanakan oleh satu pihak saja.

Kerjasama kolaboratif masing-masing pihak diikat oleh adanya kepentingan bersama untuk mencari solusi terhadap masalah atau isu tertentu, yang dirasakan oleh para pihak sangat mengganggu kepentingannya. Kemauan untuk melakukan kerjasama muncul karena adanya suatu keninginan untuk mencari solusi terhadap masalah yang dirasakan bersama oleh suatu organisasi publik dengan mitranya dari organisasi di sektor privat. Keduanya merasa bahwa masalah atau kepentingan tersebut dapat diselesaikan secara lebih mudah apabila mereka bersama-sama bekerja untuk mencari solusi terhadap masalah atau kepentingan bersama tersebut. Masalah atau kepentingan bersama menjadi sumber inspirasi dan motivasi bagi berkembangnya kolaborasi antara organisasi publik dan organisasi mitranya di sektor privat. Menurut fosler menjelaskan secara lebih rinci menjelaskan konsep kolaborasi dengan mengatakan bahwa kerjasama yang bersifat kolaboratif melibatkan kerjasama antar pihak yang intensif, termasuk adanya upaya secara sadar untuk melakukan alignment dalam tujuan, strategi, agenda, sumber daya dan aktivitas. Kedua institusi pada dasarnya memiliki tujuan yang berbeda membangun visi bersama (shared vision) dan berusaha mewujudkannya secara bersama-sama. Untuk itu mereka menyatukan atau setidaknya melakukan aliansi secara vertikal mulai dari sasaran, strategi, sampai dengan aktivitas dalam rangka mencapai tujuan bersama yang mereka yakini lebih bernilai dari tujuan yang dimiliki oleh masing-masing.

Dalam kerjasama kolaboratif, visi bersama ini menjadi dasar bagi masingmasing pihak untuk merumuskan tujuan, strategi, alokasi, sumberdaya, dan aktivitas masing-masing sehingga kesemuanya memiliki kontribusi terhadap terwujudnya visi bersama tersebut. Dalam rangka mengembangkan kerangka kerja collaborative governance dalam kajian ini, maka teori yang bersangkutan dengan tatakerangka dapat dikontekstualisasikan dengan fokus penelitian yang berbeda-beda. Sehingga dapat mengidentifikasi drivers, engagement processes, motivational attributes dan joint capacities yang dapat memungkinkan pengambilan keputusan bersama. Proses penulisan kerangka kerja dari collaborative governance dimulai dengan mencari kerangka konseptual yang relevan dengan studi empiris, yakni memahami literatur-literatur yang mengkaji cross-sector collaboration, collaborative planning, collaborative processes, network management, collaborative public management, environmental governance dan conflict resolution.

Framework collaborative governance memiliki berbagai dimensi, yaitu system context, konsep collaborative governance, dan dinamika kolaborasi. Dimensi-dimensi tersebut digambarkan seperti berikut (Balogh, 2011) pada Gambar 1.

1. Dimensi pertama digambarkan dengan kotak terluar yang merupakan ruang lingkup/ system context yang menaungi.system context ini menghasilkan peluang-peluang dan batasan-batasan dan mempengaruhi dinamika kolaborasi dalam hal permulaan dan seterusnya. Dari System Context ini nanti juga muncul Driver-driver termasuk kepemimpinan, Insentif Konsekuensi, Ketergantungan dan ketidakpastian, yang membantu menginisiasi dan mengatur arah bagi Collaborative Governance. 
Dwi Agustina, Kolaborasi Antara Aparatur Birokrasi Pemerintah Daerah Istimewa ...

2. Dimensi kedua merupakan bagian dari konsep collaborative governance yang terdiri dari dinamika kolaborasi dan aksi kolaborasi.

3. Dimensi ketiga merupakan dinamika kolaborasi yang terdiri atas tiga komponen, yaitu: principled engagement, shared motivation dan capacity for joint action.
Dalam penelitian ini juga akan membahas bagaimana setelah System context dan driver mempengaruhi kolaborasi yaitu dengan membahas dinamika dari kolaborasi tersebut. Elemen- elemen spesifik dalam setiap komponen dijelaskan pada gambar di bawah ini pada Gambar 2.

\section{Gambar 1 \\ The Integrative Framework for Collaborative Governance}

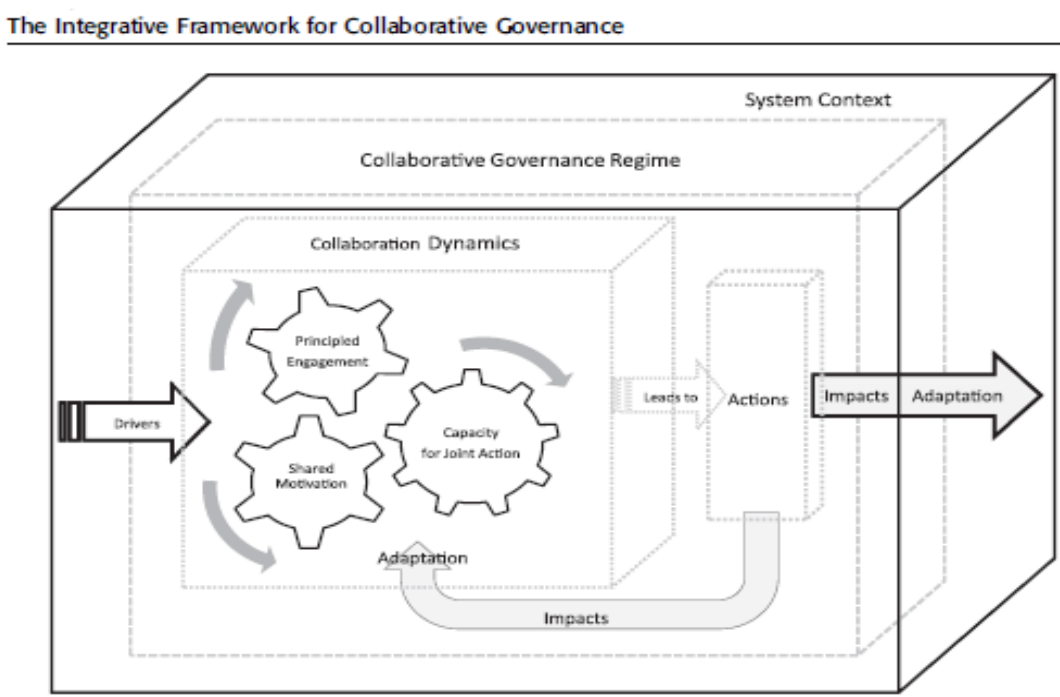

Sumber: (Balogh, 2011:6)

Gambar 2

Framework Collaborative Governance

System Context

1. Resource Conditions

2. Policy Legal

Frameworks

3. Prior Failure to

Adrdress Issues

4. Political Dynamics/

Power Relations

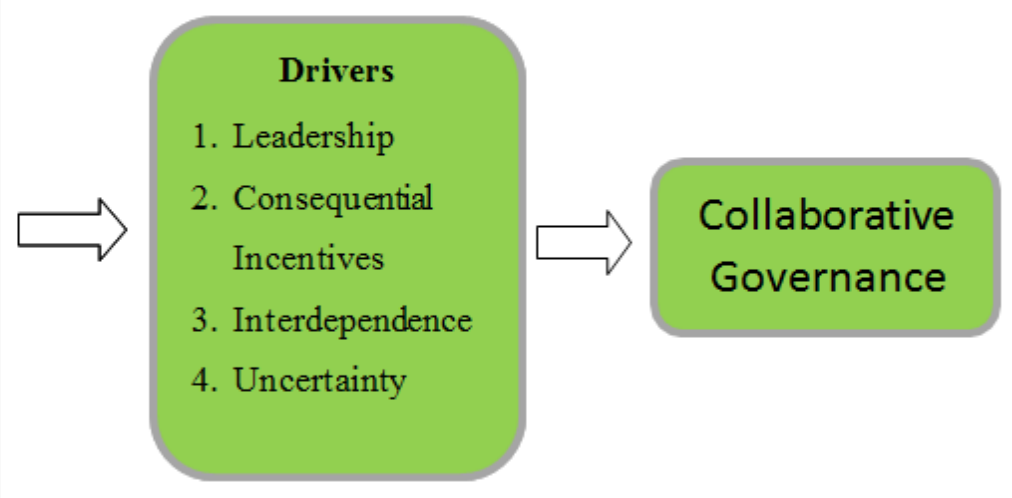

5. Network

Connectedness

6. Level of Conflict

Trust

(Tabel diadaptasi dan disesuaikan dari Model Balogh ddk: 2011) 
1. Berdasarkan kerangka penelitian di atas, System Context merupakan kondisi lingkungan yang menaungi keberlangsungan collaborative governance system context ini menciptakan peluang dan kendala yang mempengaruhi parameter umum lain dari collaborative governance. System context yang direpresentasikan dalam kerangka ini, bukan sebagai serangkaian kondisi awal tetapi sebagai ruang dari dimensi lainnya karena kondisi eksternal dapat mempengaruhi dinamika dan kinerja kolaborasi tidak hanya di awal tetapi pada setiap saat selama collaborative governance berjalan, sehingga membuka kemungkinan dan tantangan baru. Beberapa elemen utama dalam system context yang mungkin mempengaruhi sifat dan prospek collaborative governance dalam penelitian ini, antara lain: kondisi sumberdaya, kebijakan dan kerangka hukum, tingkat konflik dan kepercayaan, sosialekonomi atau budaya kesehatan dan keragaman.

Elemen system context yang dapat membedakan atau mempengaruhi collaborative governance yang terbentuk, antara lain:

a) Resource Condition, menjelaskan kondisi sumberdaya yang dimiliki apakah perlu diperbaiki, ditingkatkan atau bahkan dibatasi.

b) Policy and Legal Framework, kebijakan dan kerangka hukum termasuk administrasi, peraturan atau yudikatif.

c) Prior Failure to Adrdress Issues, pelajaran kegagalan masa lalu dapat mengambil pelajaran atas kegagalan di masa lalu masing-masing stakeholder.

d) Political Dynamics/Power Relations, Dinamika Politik atau Kekuatan Relasi adalah bagaimana dinamika politik atau kekuatan relasi yang mempengaruhi jalannya kolaborasi.

e) Network Connectedness, Hubungan jaringan dapat digolongkan kepada manajemen jaringan sebuah cara untuk membangun nilai-nilai kepemimpinan dalam tipe relasi antar aktor yang sifatnya horizontal.

f) Level of Conflict/ Trust, terjadinya konflik antara kepentingan masingmasing pihak yang bekerja sama dan bagaimana konflik tersebut mempengaruhi tingkat kepercayaan sehingga berdampak pada hubungan kerja.

2. Secara umum diakui bahwa sebuah kondisi hadir pada awal terjadinya kolaborasi dapat memfasilitasi atau mencegah kerjasama antara pemangku kepentingan dan antara instansi dan pemangku kepentingan, banyak kerangka cenderung menggabungkan system context dan kondisi dengan driver tertentu dalam kolaborasi. Namun, dalam framework ini, variabel system context dipisahkan dengan drivers, tanpa drivers maka dorongan untuk kolaborasi menjadi terhambat dan tidak berkembang. Komponen-komponen yang termasuk dalam drivers:

a) Leadership, mengacu pada sosok seorang pemimpin yang dapat berinisiatis untuk memulai dan membantu mempersiapkan sumberdaya untuk mendukung pelaksanaan collaborative governance dengan segala kapasitas yang dimilikinya.

b) Consequential incentives, mengarah pada bagian baik internal (masalah, kebutuhan akan sumber daya, kepentingan, atau kesempatan) maupun eksternal (krisis, ancaman, atau kesempatan yang bersifat situasional/ institusional) drivers untuk aksi kolaborasi. Insentif konsekuensial tidak selalu bersifat negative, dengan adanya insentif maka akan mendorong para pemimpin dan anggota dalam kerjasama akan terlibat bersama-sama.

c) Interdependence, kondisi ketika individu dan organisasi tidak dapat mencapai sesuatu dengan usaha dan kapasitas satu pihak, untuk itu mengapa tindakan kolaboratif dapat berkembang untuk dilaksanakan.

d) Uncertainty, ketidakpastian menjadi tantangan utama dalam mengelola permasalahan publik. Ketidakpastian kolektif tentang bagaimana kelompokkelompok berkolaborasi untuk menyelesaikan masalah, dengan kata lain berbagi- bagi dalam mengurangi resiko. 
Dwi Agustina, Kolaborasi Antara Aparatur Birokrasi Pemerintah Daerah Istimewa ...

Ketidakpastian kolektif tentang bagaimana mengelola masalah sosial juga berkaitan dengan driver lain yaitu interdependencel ketergantungan.

Selain teori terkait dengan Collaborative Governance penelitian ini juga mengacu pada teori yang terkait dengan bencana dan manajemen bencana, yang mana menurut United Nations Development Program (UNDP), badan PBB yang mengurusi pembangunan mendefinisikan bencana bencana sebagai berikut:

" A serious distruption of the functioning of a community or a society involving widespread human, material, economic or environmental losses and impacts, which exceeds the ability of the affected community or society to cope using its own resources"

Penyelenggaraan penanggulangan bencana adalah serangkaian upaya yang meliputi penetapan kebijakan pembangunan yang berisiko timbulnya bencana, kegiatan pencegahan bencana, tanggap darurat, dan rehabilitasi. Penyelenggaraan penanggulangan bencana bertujuan untuk menjamin terselenggaranya pelaksanaan penanggulangan bencana secara terencana, terpadu, terkoordinasi, dan menyeluruh dalam rangka memberikan perlindungan kepada masyarakat dari ancaman, risiko, dan dampak bencana. Didalam penyelenggaraan penanggulangan bencana (disaster management), risiko bencana didefinisikan sebagai interaksi antara kerentanan suatu daerah dengan ancaman bahaya (hazards) yang ada. Ancaman bahaya, khususnya bahaya yang berasal dari alam bersifat tetap karena merupakan bagian dari dinamika proses alami pembentuk struktur bumi baik dari tenaga internal maupun eksternal, sedangkan tingkat kerentanan suatu daerah dapat dikurangi melalui berbagai usaha peningkatan kesiapsiagaan, mitigasi struktural maupun non struktural, sehingga kemampuan dalam menghadapi ancaman tersebut semakin meningkat. Penyelenggaraan penanggulangan bencana meliputi tahap:

\section{Prabencana.}

Dalam tahapan ini menurut Undangundang Penanggulangan Bencana No. 24 Tahun 2007 di bagai ke dalam dua tahapan yaitu

\section{Situasi Tidak Terjadi Bencana}

Penyelenggaraan penanggulangan bencana dalam situasi tidak terjadi bencana dapat dilakukan melalui penelitian dan pengembangan kebencanaan. Penyelenggaraan penanggulangan bencana dalam situasi tidak terjadi bencana meliputi: 1)Perencanaan penanggulangan bencana,2)Pengurangan risiko bencana.,3)Pencegahan,4)Pemaduan dalam perencanaan pembangunan, 5)Persyaratan analisis risiko bencana, 6)Pelaksanaan dan Penegakan rencana tata ruang Dan ketentuan pendirian bangunan, 7)Pendidikan dan pelatihan

\section{Situasi Terdapat Potensi Bencana.}

Penyelenggaraan Penanggulangan Bencana dalam situasi terdapat potensi bencana di dalam Undang-undang No.24 Tahun 2007dalam Pasal 44 meliputi tahapan: Kesiapsiagaan, dan Mitigasi.

\section{Tanggap Darurat}

Tanggap darurat bencana adalah serangkaian kegiatan yang dilakukan dengan segera pada saat kejadian bencana untuk menangani dampak buruk yang ditimbulkan, yang meliputi kegiatan penyelamatan dan evakuasi korban, harta benda, pemenuhan kebutuhan dasar, pelindungan, pengurusan pengungsi, penyelamatan, serta pemulihan prasarana dan sarana.

\section{Pasca Bencana}

Pasca bencana adalah situasi setelah tanggap darurat bencana dalam Tahapan ini yang menjadi focus adala pemulihan dan pembangunan kembali baik masyarakat maupun fasilitas- fasilitas umum yang ada di masyarakat. Dalam tahapan pasca dibagi menjadi dua tahapan, yaitu: Rehabilitasi dan rekonstruksi.

Penelitian ini menggunakan metode kualitatif, Menurut Locke, Spirduso, \& Silverman", "penelitian kualitatif pada 
hakikatnya bertujuan untuk memahami situasi, peristiwa, kelompok, ataupun interaksi sosial tertentu pada setting alamiah". penelitian ini menerapkan pendekatan studi kasus.

\section{PEMBAHASAN}

Pada bagian ini akan bagaiama kolaborasi antara Aparatur Pemerintah DIY dan Forum PRB DIY dalam penanggulangan bencana di Provinsi Daerah Yogyakarta. Kolaborasi yang terjadi lebih dilihat bagaimana kolaborasi ini berawal serta bagaimana masing-masing stakeholder menjalankan perannya baik aparatur birokrasi dan Anggota Forum PRB DIY. Pemerintah DIY menyadari bahwa dalam penyelenggaraan penanggulangan bencana tidak hanya dapat diselesaikan oleh salah satu pihak saja, baik pemerintah, LSM/NGO, Komunitas,Swasta ataupun masyarakat. Sesuai dengan amanat Undang-undang No 24 Tahun 2007 bahwa penyelenggaraan penanggulangan bencana harus dilakukan dengan melibatkan banyak pihak di dalamnya.

Kolaborasi yang terjadi dalam pelasanaan kegiatan Penanggulangan Bencana di Daerah Istimewa Yogyakarta.
Pemaparan merujuk kepada dimensi Collaborative Governance yang di dasari pada System Context dan Driver. kolaborasi yang terjadi tertuju pada keterlibatan setiap pihak yang didasarkan kerjasama. Setiap pihak memiliki tugas dan tanggung jawab yang berbeda-beda. Perbedaan tugas dan tanggung jawab merupakan karakteristik yang tersendiri dalam kolaborasi ini. .

Untuk melihat kolaborasi yang terrjadi antara Pemerintah DIY dan Forum PRB DIY dibagi kedalam tahapan-tahapan Manajemen Penanggulangan bencana yaitu:

\section{Kolaborasi Aparatur Pemerintah DIY dan Forum PRB DIY Dalam Tahapan Pra Bencana.}

Dalam situasi pra bencana terdiri dari dua tahapan yaitu tahap Situasi tidak tejadi bencana dan situasi berpotensi terjadinya bencana. Untuk melihat kolaborasi antara Pemerintah DIY dan Forum PRB DIY dalam tahap pra bencana kita akan melihatnya kedalam dimensi Collaborative governance, indikator kolaborasi yang dilakukan oleh Pemerintah dan Forum PRB dalam tahapan bencana yang tentunya memiliki kelemahan serta kelebihan dalam berkolaborasi. Kelemahan dan kelebihan tersebut dapat dilihat melalui tabel dibawah Ini:

\section{Tabel 1. Kelebihan dan kelemahan Dimensi Kolaborasi antara Pemerintah DIY dan Forum} PRB DIY dalam Tahapan Pra Bencana

\begin{tabular}{|c|c|c|}
\hline $\begin{array}{c}\text { Dimensi } \\
\text { Collaborative } \\
\text { Governance }\end{array}$ & Kelebihan & Kelemahan \\
\hline \multicolumn{3}{|c|}{ Sistem Konteks } \\
\hline 1.sumber Daya & $\begin{array}{l}\text { Pemerintah Banyak dibantu oleh } \\
\text { anggota Forum PRB pada Tahapan } \\
\text { ini, anggota Forum banyak terlibat } \\
\text { dalam pembuatan perencanaan } \\
\text { kegiatan } \\
\text { pengurangan resiko bencana. }\end{array}$ & $\begin{array}{l}\text { Pemerintah terkesan lebih pasif } \\
\text { karena sumber daya yang } \\
\text { digunakan banyak dari pihak non } \\
\text { Pemerintah (Anggota Forum } \\
\text { PRB) hal ini dikarenakan para } \\
\text { anggota forum PRB berasal dari } \\
\text { tenaga ahli kebencanaan. }\end{array}$ \\
\hline
\end{tabular}


Dwi Agustina, Kolaborasi Antara Aparatur Birokrasi Pemerintah Daerah Istimewa ...

\begin{tabular}{|c|c|c|}
\hline $\begin{array}{c}\text { Dimensi } \\
\text { Collaborative } \\
\text { Governance }\end{array}$ & Kelebihan & Kelemahan \\
\hline $\begin{array}{l}\text { 2.kebijakan dan } \\
\text { kerangka Hukum }\end{array}$ & $\begin{array}{l}\text { Dalam penyusunan } \\
\text { pemerintah mendapatkan banyak } \\
\text { masukan dari } \quad \text { berbagai } \\
\text { stakeholder lain. Bagi forum } \\
\text { PRB yang diberikan kesempatan } \\
\text { menyusun kebijakan tentunya } \\
\text { memperlihatkan bagaimana } \\
\text { pemerintah DIY sudah mulai } \\
\text { menerapkan sistem bottom up } \\
\text { dengan memasukkan aspirasi dari } \\
\text { perwakilan masyakarakat terkait } \\
\text { kebijakan yang disusun. }\end{array}$ & $\begin{array}{l}\text { Adanya bantuan dari anggota } \\
\text { forum PRB dalam menyusun } \\
\text { kebijakan dan peraturan } \\
\text { perundang-undangan membuat } \\
\text { seolah pemerintah DIY lebih } \\
\text { mempercayakan penyusunan } \\
\text { kebijakan dilakukan oleh } \\
\text { forum, padahal pemerintah } \\
\text { seharusnya lebih memiliki } \\
\text { peran dalam meyusun sebuah } \\
\text { kebijakan. }\end{array}$ \\
\hline 3.Pembelajaran & Adanya kolaborasi yang terjadi & Pertemuan yang kurang rutin \\
\hline masa lalu & $\begin{array}{l}\text { dalam tahapan pra bencana } \\
\text { membuat adanya pertukaran } \\
\text { informasi yang terjadi diantara } \\
\text { Pemerintah DIY dan anggota } \\
\text { Forum PRB DIY, pengalaman } \\
\text { dari masing-masing dapat } \\
\text { dijasikan pelajaran yang } \\
\text { bermanfaat ketika menyusun } \\
\text { program serta sebagai early } \\
\text { warning tersendiri bagi para aktor } \\
\text { ketika mengalami situasi yang } \\
\text { berpotensi bencana. }\end{array}$ & $\begin{array}{l}\text { antara pemerintah dan anggota } \\
\text { Forum PRB membuat proses } \\
\text { pembelajaran dan saling tukar } \\
\text { informasi dirasakan masih } \\
\text { kurang. }\end{array}$ \\
\hline $\begin{array}{l}\text { 4.Dinamika } \\
\text { Politik/Kekuatan } \\
\text { Hubungan }\end{array}$ & $\begin{array}{l}\text { Dinamika yang terjalin dengan } \\
\text { baik dalam tahapan pra bencana } \\
\text { mebuat adanya program-program } \\
\text { yang berbasis pengurangan risiko } \\
\text { bencana dapat dimasukkan ke } \\
\text { dalam program-program atau }\end{array}$ & $\begin{array}{l}\text { Situasi dinamika politik yang } \\
\text { terkadang berubah dapat } \\
\text { merubah prioritas kegiatan } \\
\text { yang diajukan. Hal ini terkait } \\
\text { dengan dukungan untuk tetap } \\
\text { memprioritaskan aspek }\end{array}$ \\
\hline
\end{tabular}




\begin{tabular}{|c|c|c|}
\hline $\begin{array}{l}\text { Dimensi } \\
\text { Collaborative } \\
\text { Governance }\end{array}$ & Kelebihan & Kelemahan \\
\hline & $\begin{array}{l}\text { rencana kerja yang dibuat oleh } \\
\text { pemerintah daerah ataupun } \\
\text { anggota forum PRB. }\end{array}$ & $\begin{array}{l}\text { pengurangan risiko bencana } \\
\text { dalam setiap program kegiatan. }\end{array}$ \\
\hline 5.Jaringan & $\begin{array}{l}\text { Dengan jaringan yang dimiliki } \\
\text { oleh Pemerintah Diy dan anggota } \\
\text { Forum PRB DIY membuat } \\
\text { adanya nilai dan norma yang } \\
\text { dianut para anggota sehingga } \\
\text { pondasi awal untuk pertukaran } \\
\text { sumberdaya dapat meudahkan } \\
\text { karena masing-masing anggota }\end{array}$ & $\begin{array}{l}\text { Pelibatan pertukaran sumber } \\
\text { daya yang terkadang hanya } \\
\text { melibatkan anggota yang sering } \\
\text { terlibat membuat anggota lain } \\
\text { menjadi kurang berpartisipasi. }\end{array}$ \\
\hline & sudah memahami peran nya. & \\
\hline $\begin{array}{l}\text { 6.Tingkat Konflik } \\
\text { /Kepercayaan }\end{array}$ & $\begin{array}{l}\text { Dengan memiliki tujuan yang sama } \\
\text { yaitu dalam tahap pra bencana } \\
\text { focus dari tujuan berkolaborasi } \\
\text { adalah upaya pengurangan risiko } \\
\text { bencana maka potensi konflik yang } \\
\text { terjadi sangatlah kecil. }\end{array}$ & $\begin{array}{l}\text { Konflik yang sangat kecil } \\
\text { membuat kolaborasi yang terjadi } \\
\text { itterkesan datar sehingga tidak ada } \\
\text { menimbulkan masalh bagi } \\
\text { organisasi yang terlibat hal ini } \\
\text { nantinya akan mebuat kejenuhan } \\
\text { tersendiri yang mebuat potensi } \\
\text { konflik dari ekternal dapat } \\
\text { terjadi. }\end{array}$ \\
\hline \multicolumn{3}{|c|}{ Pendorong } \\
\hline A. Kepemimpinan & $\begin{array}{l}\text { adanya dukungan dari seluruh } \\
\text { pimpinan masing-masing } \\
\text { membuat kolaborasi ini dapat } \\
\text { berjalan dengan baik. }\end{array}$ & $\begin{array}{l}\text { Pemimpin dari forum PRB dan } \\
\text { Pemerintah DIY kedepannya agar } \\
\text { tlebih dapat merangkul semua } \\
\text { pihak baik dari pemerintah } \\
\text { maupun anggota forum. }\end{array}$ \\
\hline Tonsekuensi insentif & \multicolumn{2}{|c|}{ 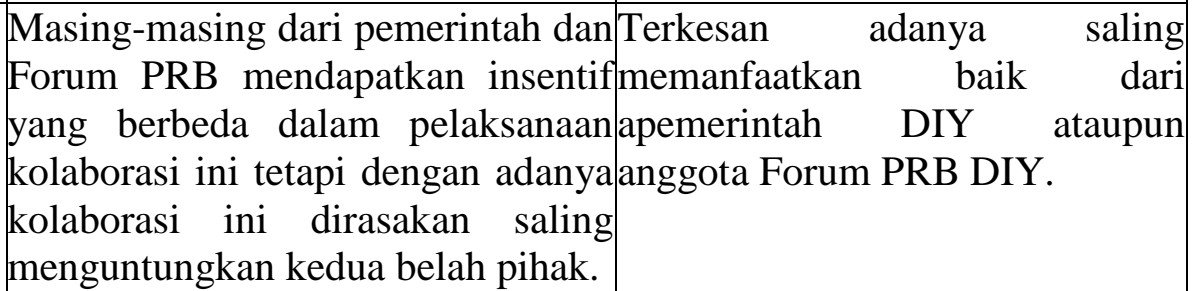 } \\
\hline $\begin{array}{l}\text { C. Saling } \\
\text { ketergantungan }\end{array}$ & $\begin{array}{l}\text { Pemerintah dan Forum saat ini } \\
\text { bekerja secara bersama dalam } \\
\text { mengedepankan } \\
\text { pengurangan risiko bencana, }\end{array}$ & 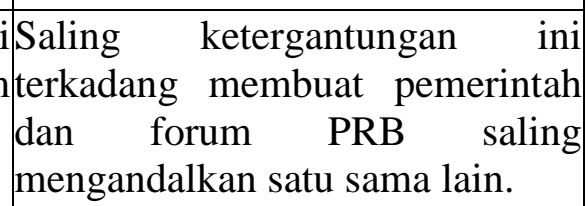 \\
\hline
\end{tabular}


Dwi Agustina, Kolaborasi Antara Aparatur Birokrasi Pemerintah Daerah Istimewa ...

\begin{tabular}{|c|c|c|}
\hline $\begin{array}{c}\text { Dimensi } \\
\text { Collaborative } \\
\text { Governance }\end{array}$ & Kelebihan & Kelemahan \\
\hline & $\begin{array}{l}\text { pemerintah dan Forum tidak dapat } \\
\text { dipisahkan dalam menentukan } \\
\text { program }\end{array}$ & \\
\hline D. ketidakpastian & $\begin{array}{l}\text { Kegiatan penanggulangan } \\
\text { bencana pada tahapan pra } \\
\text { bencana adalah kegiatan yang } \\
\text { tidak memiliki waktu yang pas, } \\
\text { tetapi dengan adanya persiapan } \\
\text { terkait kegiatan tentunya } \\
\text { bermanfaat pada saat tanggap } \\
\text { Darurat }\end{array}$ & $\begin{array}{l}\text { Ketidakpastian } \\
\text { menghadapi potensi bencana } \\
\text { terkadang membuat seluruh } \\
\text { pihak lengah dalam pembuatan } \\
\text { kegiatan penguragan risiko } \\
\text { bencana. }\end{array}$ \\
\hline
\end{tabular}

Kolaborasi Aparatur Pemerintah DIY dan Forum PRB DIY Dalam Tahapan Tanggap Darurat

Tanggap darurat bencana adalah serangkaian kegiatan yang dilakukan dengan segera pada saat kejadian bencana untuk menangani dampak buruk yang ditimbulkan, yang meliputi kegiatan penyelamatan dan evakuasi korban, harta benda, pemenuhan kebutuhan dasar, pelindungan, pengurusan pengungsi, penyelamatan, serta pemulihan prasarana dan sarana. Tanggap darurat bencana merupakan kegiatan yang sangat krusial terutama berkaitan dengan hajat hidup banyak orang. Menurut Shaluf dalam Kusumasari $^{11}$ mengatakan tujuan dari kegiatan ini untuk menyelamatkan nyawa, mengurangi kerusakan harta benda dan meningkatkan pemulihan awal dari insiden tersebut. Gambaran tersebut memperlihatkan bahwa urgensi dari tanggap darurat sangat penting terutama koordinasi yang dilakukan secara tepat waktu guna meminimalisir korban yang ditimbulkan. Penyelenggaraan penanggulangan bencana pada saat tanggap darurat dikendalikan oleh kepala BNPB atau kepala BPBD sesuai dengan kewenangannya.

Untuk melihat kolaborasi antara Pemerintah DIY dan Forum PRB DIY dalam tahap tanggap darurat kita akan melihatnya kedalam dimensi Collaborative governance, kolaborasi yang terjadi diantara Pemerintah DIY dan Forum PRB DIY pada masa tanggap darurat. Beberapa indikator kolaborasi yang dilakukan oleh Pemerintah dan Forum PRB dalamtahapan tanggap darurat dijabarkan diatas tentunya memiliki kelemahan serta kelebihan dalam berkolaborasi. Kelemahan dan kelebihan tersebut dapat dilihat melalui tabel dibawah Ini:

Tabel 2. Kelebihan dan kelemahan dimensi Kolaborasi antara Pemerintah DIY dan Forum PRB DIY dalam Tahapan Tanggap Darurat

\begin{tabular}{|c|c|c|}
\hline $\begin{array}{c}\text { Dimensi Collaborative } \\
\text { Governance }\end{array}$ & Kelebihan & Kelemahan \\
\hline \multicolumn{3}{|c|}{ Sistem Konteks } \\
\hline
\end{tabular}




\begin{tabular}{|c|c|c|}
\hline $\begin{array}{c}\text { Dimensi Collaborative } \\
\text { Governance }\end{array}$ & Kelebihan & Kelemahan \\
\hline 1.Sumber Daya & $\begin{array}{l}\text { Dalam masa tanggap darurat } \\
\text { pelibatan forum PRB hanya } \\
\text { sebatas pada pembuatan gugus } \\
\text { tugas saja sehingga pemerintah } \\
\text { masih terbantu sampai pembuatan } \\
\text { gugus tugas kegiatan tanggap } \\
\text { darurat. }\end{array}$ & $\begin{array}{l}\text { Peran forum yang hanya sampai } \\
\text { pembuatan gugus tugas kegiatan } \\
\text { tanggap darurat membuat forum } \\
\text { tidak berperan banyak dalam masa } \\
\text { tanggap darurat. }\end{array}$ \\
\hline $\begin{array}{l}\text { 2.Kebijakan dan } \\
\text { kerangka Hukum }\end{array}$ & $\begin{array}{l}\text { Dalam penyusunan peraturan } \\
\text { terkait kegiatan tanggap darurat } \\
\text { dibantu oleh anggota forum } \\
\text { sehingga peraturan yang berkaitan } \\
\text { dengan tanggap darurat masih } \\
\text { melibatkan aktor non pemerintah. }\end{array}$ & 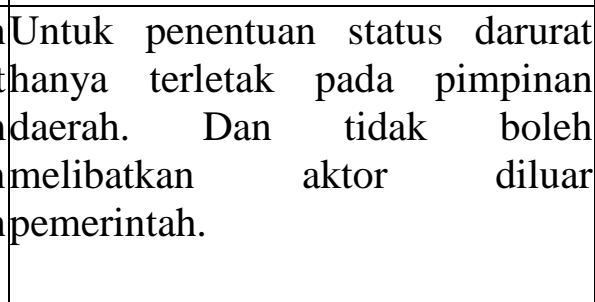 \\
\hline \multirow[t]{2}{*}{$\begin{array}{l}\text { 3.Pembelajaran } \\
\text { masa lalu }\end{array}$} & \multicolumn{2}{|c|}{$\begin{array}{l}\text { Pertukaran informasi yang terjadi Informasi yang didapatkan belum } \\
\text { dari pengalaman masa tanggap tentu sesuai dengan jenis bencana } \\
\text { darurat yang pernah } \\
\text { dialami oleh anggota forum dan }\end{array}$} \\
\hline & $\begin{array}{l}\text { pemerintah membuat adanya } \\
\text { proses pembelajaran dalam masa } \\
\text { tanggap darurat. }\end{array}$ & $\begin{array}{l}\text { anggota forum juga harus } \\
\text { menganalisis kembali apakah } \\
\text { pelajaran dari pengalaman di masa } \\
\text { lalu dapt diterapkan. }\end{array}$ \\
\hline $\begin{array}{l}\text { 4.Dinamika } \\
\text { Politik/Kekuatan } \\
\text { Hubungan }\end{array}$ & \multicolumn{2}{|c|}{ 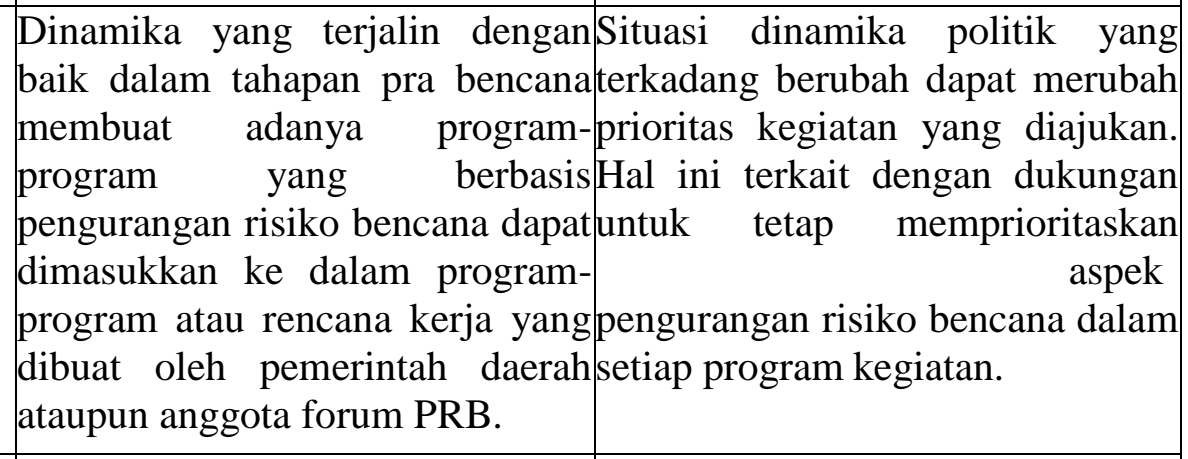 } \\
\hline 7.Jaringan & \multicolumn{2}{|c|}{$\begin{array}{l}\text { Dengan jaringan yang dimiliki } \mid \text { Ketergantungan } \\
\text { oleh Pemerintah DIY dan anggotapemerintah dan anggota forum } \\
\text { Forum PRB DIY membuat PRB dalam masa pra bencana } \\
\text { kegiatan bekerjasama dalam masatentunya mempengaruhi dalam } \\
\text { tanggap darurat tidaklah sulit kegiatan tanggap darurat. } \\
\text { untuk dijalankan. }\end{array}$} \\
\hline $\begin{array}{l}\text { 8.Tingkat Konflik } \\
\text { /Kepercayann }\end{array}$ & $\begin{array}{l}\text { Tingkat konflik sangatlah kecil } \\
\text { karena dalam masa tanggap } \\
\text { darurat tujuan utama dari seluruh } \\
\text { stakeholders adalah bagaiamana } \\
\text { penyelamatan korban bencana. }\end{array}$ & $\begin{array}{l}\text { Tidak adanya konflik membuat } \\
\text { anggota forum PRB dan } \\
\text { Pemerintah DIY tidak terlalu } \\
\text { mempedulikan hubungan yang } \\
\text { terjalin diantara mereka. }\end{array}$ \\
\hline \multicolumn{3}{|c|}{ Pendorong } \\
\hline
\end{tabular}


Dwi Agustina, Kolaborasi Antara Aparatur Birokrasi Pemerintah Daerah Istimewa ...

\begin{tabular}{|c|c|c|}
\hline $\begin{array}{c}\text { Dimensi Collaborative } \\
\text { Governance }\end{array}$ & Kelebihan & Kelemahan \\
\hline 1.Kepemimpinan & $\begin{array}{l}\text { adanya dukungan dari seluruh } \\
\text { pimpinan masing-masing } \\
\text { membuat kolaborasi ini dapat } \\
\text { berjalan dengan baik. }\end{array}$ & $\begin{array}{l}\text { Pemimpin dari forum PRB dan } \\
\text { Pemerintah DIY kedepannya } \\
\text { agar lebih dapat merangkul } \\
\text { semua pihak baik dari } \\
\text { pemerintah maupun anggota } \\
\text { forum. }\end{array}$ \\
\hline
\end{tabular}

\section{Kolaborasi Aparatur Pemerintah DIY dan Forum PRB DIY Dalam Tahapan Pasca Bencana}

Menurut Peraturan Daerah Daerah Istimewa Yogyakarta No. 8 Tahun 2010 Pasca bencana adalah situasi setelah tanggap darurat bencana dalam Tahapan ini yang menjadi fokus adala pemulihan dan pembangunan kembali baik masyarakat maupun fasilitas-fasilitas umum yang ada di masyarakat. Dalam tahapan pasca bencana forum PRB tidak berperan secara resmi, disini anggota Forum PRB ikut terjun dalam kegiatan tetapi tidak mengatasnamakan Forum PRB melainkan dengan bendera masing-masing organisasi. Dalam penjelasan dibawah peneliti mencoba menganalisis bagaiamana kolaborasi yang terjadi antara anggota Forum PRB dan Pemerintah DIY walaupun sudah tidak membawa nama Forum PRB secara penuh untuk melihat kolaborasi antara Pemerintah DIY dan Forum PRB DIY dalam tahap pra bencana kita akan melihatnya kedalam dimensi Collaborative governance sebagai berikut:

Dari paparan telah dijabarkan bagaimana kolaborasi yang terjadi diantara Pemerintah DIY dan stakeholders lain pada tahapan pasca bencana. Beberapa indikator kolaborasi yang dilakukan oleh Pemerintah dan Forum PRB dalam tahapan pasca bencana dijabarkan diatas tentunya memiliki kelemahan serta kelebihan dalam berkolaborasi. Kelemahan dan kelebihan tersebut dapat dilihat melalui tabel dibawah Ini:

Tabel 3. Kelebihan dan kelemahan dimensi Kolaborasi antara Pemerintah DIY dan Forum PRB DIY dalam Tahapan Pasca Bencana

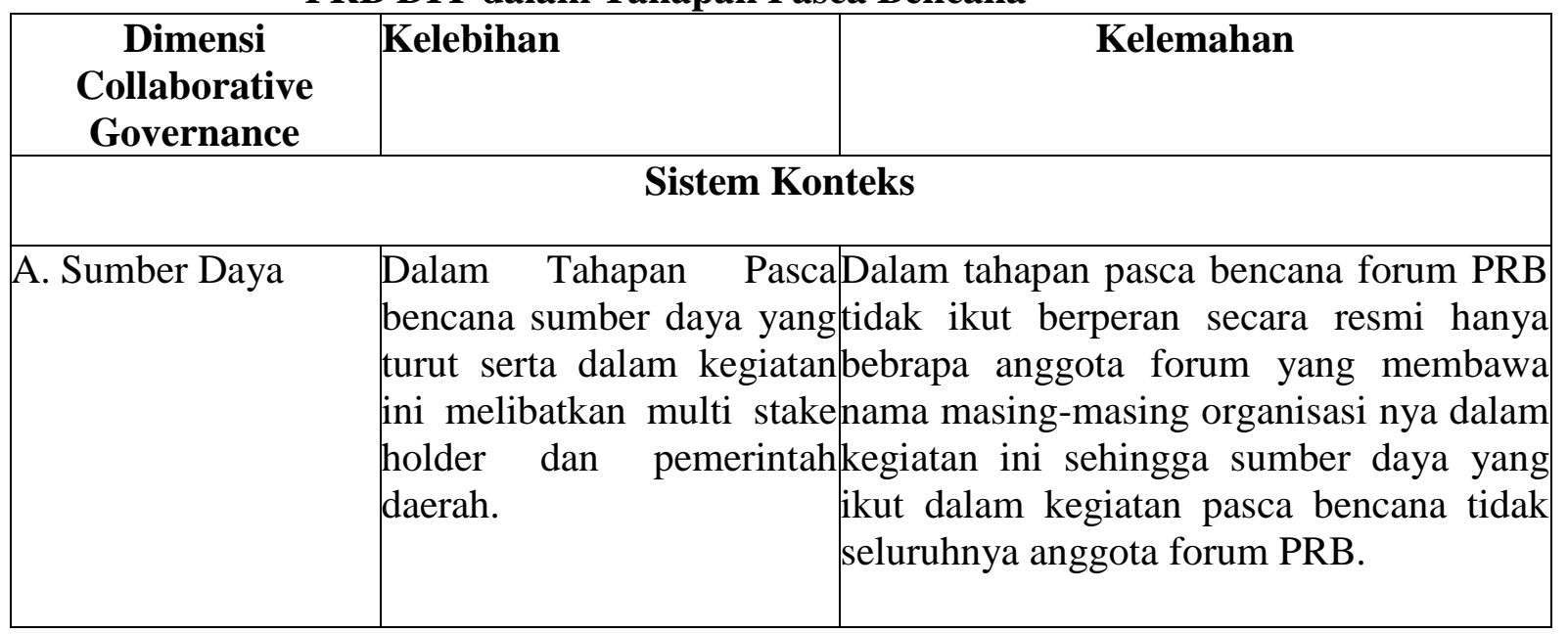




\begin{tabular}{|c|c|c|}
\hline $\begin{array}{l}\text { Dimensi } \\
\text { Collaborative } \\
\text { Governance } \\
\end{array}$ & Kelebihan & Kelemahan \\
\hline $\begin{array}{l}\text { B. Kebijakan dan } \\
\text { kerangka Hukum }\end{array}$ & \begin{tabular}{llr} 
Dalam & \multicolumn{2}{c}{ penyusunan } \\
peraturan & terkait & kegiatan \\
pasca bencana dibantu oleh \\
anggota & forum & sehingga \\
peraturan & yang & berkaitan \\
dengan & pasca & masih \\
melibatkan & aktor & non \\
pemerintah. & &
\end{tabular} & $\begin{array}{l}\text { Dalam pembuatan kebijakan untuk } \\
\text { pemulihan pasca bencana ditentukan } \\
\text { secara penuh oleh pemerintah daerah. }\end{array}$ \\
\hline $\begin{array}{l}\text { C. Pembelajaran di } \\
\text { masa lalu }\end{array}$ & \begin{tabular}{|lr|}
\multicolumn{3}{|c|}{ Keterlibatan berbagai pihak } \\
dalam upaya pemulihan \\
pasca bencana & dapat \\
menjadi ajang & saling \\
sharing & beberapa \\
stakeholder yang terkait.
\end{tabular} & $\begin{array}{l}\text { Tidak adanya kolaborasi secara resmi } \\
\text { antara pemerintah dan forum PRB } \\
\text { sehingga pertukaran pembelajaran di masa } \\
\text { lalu antara forum PRB dan pemerintah } \\
\text { kurang terjadi. }\end{array}$ \\
\hline $\begin{array}{l}\text { D. Dinamika } \\
\text { Politik/Kekuata n } \\
\text { Hubungan }\end{array}$ & $\begin{array}{l}\text { Dinamika yang terjalin } \\
\text { dengan baik dalam tahapan } \\
\text { pasca bencana membuat } \\
\text { kegiatan- } \\
\text { kegiatan pemulihan pasca } \\
\text { bencana dapat berjalan } \\
\text { dengan baik. }\end{array}$ & $\begin{array}{l}\text { Situasi dinamika politik dalam pasca } \\
\text { bencana berpengaruh dalam kegiatan- } \\
\text { kegiatan yang direncanakan untuk } \\
\text { pemulihan pasca bencana. }\end{array}$ \\
\hline E. Jaringan & $\begin{array}{l}\text { Dengan jaringan yang } \\
\text { dimiliki oleh Pemerintah } \\
\text { DIY dan organisasi lain } \\
\text { dapat bekerjasama dalam } \\
\text { masa pemulihan. }\end{array}$ & $\begin{array}{l}\text { Kurangnya koordinasi antara pihak } \\
\text { dalam tahapan ini membuat kegiatan } \\
\text { pemulihan yang dilakukan organisasi- } \\
\text { organisasi diluar pemerintah kurang } \\
\text { mendapat perhatian/dukungan dari } \\
\text { Pemerintah }\end{array}$ \\
\hline $\begin{array}{l}\text { F. Tingkat } \\
\text { Konflik/Keperc } \\
\text { Ayaan }\end{array}$ & \begin{tabular}{|lr} 
Upaya & penyelesaian \\
konflik & dengan \\
memfokuskan & tujuan \\
utama dalam & kegiatan \\
pemulihan & menjadi \\
alternative & tersendiri \\
dalam & penyelesaian \\
konflik yang terjadi.
\end{tabular} & $\begin{array}{l}\text { Dalam masa pemulihan ini sangat } \\
\text { memungkinkan terjadinya konflik antar } \\
\text { masyarakat dan pemerintah terkait } \\
\text { dengan relokasi. }\end{array}$ \\
\hline \multicolumn{3}{|c|}{ Pendorong } \\
\hline A. Kepemimpinan & $\begin{array}{l}\text { adanya dukungan dari } \\
\text { seluruh pimpinan } \\
\text { masing-masing membuat } \\
\text { kolaborasi ini dapat } \\
\text { berjalan dengan baik. }\end{array}$ & $\begin{array}{l}\text { Kedepannya sebaiknya seluruh pimpinan } \\
\text { dapat berkoordinasi dengan baik, } \\
\text { sehingga konflik-konlik yang terjadi } \\
\text { dapat diminimalkan. }\end{array}$ \\
\hline
\end{tabular}




\section{KESIMPULAN DAN SARAN}

\section{Kesimpulan}

Dari analisis data dan paparan terkait kolaborasi Aparatur Birokrasi Pemerintah Daerah DIY dan Forum PRB DIY dalam penyelenggaraan penanggulangan bencana di Daerah Istimewa Yogyakarta maka dapat ditarik kesimpulan sebagai berikut:

1. Kolaborasi yang terjadi antara Aparatur Birokrasi pemerintah DIY dan Forum PRB DIY dalam penyelenggaraan penanggulangan bencana di DIY terjalin dengan baik dalam tahap pra bencana hal ini dikarenakan peran Forum PRB sangat banyak dalam tahapan pra bencana baik dari segi dimensi sistem konteks yaitu sumber daya, kebijakan, pelajaran di masa lalu, dinamika politik, jaringan, dan tingkat konflik serta faktor pendorong yang baik dalam tahapan pra bencana.

2. Kolaborasi yang terjadi antara Aparatur Birokrasi pemerintah DIY dan Forum PRB DIY dalam penyelenggaraan penanggulangan bencana di DIY pada tahap tanggap darurat melemah hal ini dikarenakan peran dari Forum PRB DIY yang berkurag dalam tahapan ini. Hal ini dikarenakan peran Forum PRB DIY hanya sampai pembagian Kluster dalam tahapan tanggap darurat.

3. Kolaborasi yang terjadi antara Aparatur Birokrasi pemerintah DIY dan Forum PRB DIY dalam penyelenggaraan penanggulangan bencana di DIY pada tahap pra bencana sangat melemah hal ini dikarenakan peran Forum PRB dalam tahap Pasca Bencana sudah tidak ada lagi, yang ada hanyalah kerja sama antara Pemerintah dengan anggota Forum dengan membawa nama organisasi masing-masing tidak membawa nama forum PRB DIY.

\section{Saran}

Beberapa saran, ide atau gagasan yang dapat direkomendasikan kepada Pemerintah Daerah Yogyakarta, Badan Penanggulangan Bencana Daerah, dan Anggota Forum PRB
DIY adalah Sebagai berikut:

1. Pada tahapan pra bencana kolaborasi yang terjadi perlu dipertahankan, hal ini dikarenakan sangat membantu kinerja pemerintah dan forum PRB DIY dalam upaya pengurangan risiko bencana.

2. Kolaborasi antara Pemerintah DIY dan Forum PRB DIY dalam tahap tanggap darurat seharusnya jangan melemah tetapi harus semakin menguat hal ini agar tahap tanggap darurat dapat dilakakukan dengan baik apabila adanya kolaborasi dari seluruh stakeholder sebagai upaya pengurangan korban akibat terjadinya bencana.

3. Pada tahap pasca bencana sebaiknya terjalin Kolaborasi antara Aparatur Birokrasi pemerintah DIY dan Forum PRB DIY dalam penyelenggaraan penanggulangan bencana di DIY yang lebih baik. Dengan tetap melibatkan forum PRB DIY dalam kegiatan-kegiatan pasca bencana. hal ini tentunya juga dapat menjadi evaluasi bagi seluruh stakeholder nantinya ketika pembuatan kegiatan pra bencana.

4. Perlu adanya peningkatan kapasitas oleh seluruh stakeholder yang terlibat dalam kegiatan penanggulangan bencana agar kegiatan-kegiatan penanggulangan bencana dapat berjalan lebih baik lagi.

\section{DAFTAR PUSTAKA}

Ansell dan Gash. 2007. Collaborative Governance in Theory and Practice, Journal of Public Administration Reesearch and Theory. Published by Oxford University Press

Balogh, S, dkk. 2011. An Integrative Framework for Collaborative Governance, Journal of Public Administration Research and Theory.

Blaikie,P.2002."Vulnerability and Disaster" dalam The Companion to Development Studies. V.Desai dan R.Potter (Eds). London:Arnold3

Charoengnngam, C., \& Leungbootnak, N. (2005). Post-Tsunami Disaster 
Reconstruction Management : A Case Study of Thailand. Asian Institute og Technology.

Choi, T., \& Robertson, P. J., Caucuses in collaborative governance: Modeling the for an emerging era; Public Administration Review, 70(s1), s89s99; 2010

Coppola,D.P. (2007). Introduction to International Disaster Management. Burlington,MA:Elseiver.

Direktorat Riset dan Pengabdian Masyarakat. (2007). Kajian Kebijakan Penanggulangan Banjir di Indonesia,2007. Kajian Kebijakan Penanggulanga:Partisipasi Masyarakat. Jakarta.Universitas Indonesia

De Leeuw, A.C.J., 2000, Bedrijfskunding Management, Van Gorcum, Assen, Dutch D.Ngar-yin dan P. Hills. 2010. Collaborative Governance for Sustainable Development: Wind ResourceAssessment in Xinjiang and Guangdong Province, China. Copyroght (C2010 John Wiley \& Sons, Ltd and ERP Environment.Wiley online Library.

Dwiyanto, Agus. 2011. Manajemen Pelayanan Publik: Peduli, Inklusif, dan Kolaboratif. Yogyakarta: Gadjah Mada University. Dynes,RR., Quarentelli, E.L., \& Kreps, G.A.(1972. A Perspective On Disaster. Newark:Disaster Research Center, University of Delaware.

Emergency Management Australia.1998. Australian Emergency Manual Series. Part I. Manual 3.ACT.Australia: EMA

Fadhilah,Ifan Rasyid.2013.Skripsi: Manajemen Jaringan Organisasional: Studi Kasus FPRB (Forum Pengurangan Resiko Bencana) Dalam Bencana Merapi 2010. Jurusan Politik dan Pemerintahan .UGM: Yogyakarta.

Fosler,R.S. (2002). Working Better Together : How Government, Business, and Profit Organizations Can Achieve Public Purposes through Cross Sector Collaborations, Aliances, and Partnership. Washington, D.C/ /;
Independetn Sector

Gillespie, D.F., \& Streeter, C.L. (1987). Conceptualizing and Measuring Disaster Preparedness. International Journal of Mass Emergencies and

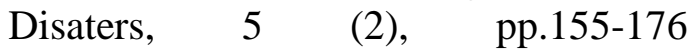
Godschalk,D.R.,(1991). Disaster Mitigation and Hazard Management. In T.Drabek\&G.Hoetmer $(E d s)$, Emergency Management: Priciples and Practice for Local Government. Washington, DC: International City Management Association.

Hardaker,J.B., Huirne R.B.M.and Anderson,J.R., 1997, Coping with risk in agriculture. CAB International, Wallingford, United Kingdom

Kaufan and Dake.2009. Understanding and Advancing Cross Sector Collaboration in Homeland Security and Emergency Management.

King,D. (2007). Organization in Disaster. Natural Hazards, 40, pp.657-665 Kirchenbaum,Alan.2004. Chaos Organization and Disaster Management.Marcel Dekker.New York

Kumorotomo, Wahyudi. dkk, 2013. Transformasi Pelayanan Jakarta Commuter Line: Studi Tentang Collaborative Governance di Sektor Publik. Jurusan Manajemen dan Kebijakan PUblik, FISIPOL, UGM

Kusumasari, Bevaola.2014.Manajemen Bencana dan Kapabilitas Pemerintah Lokal.Gava media: Yogyakarta.

Labadie,J.R.(1984).Problems in Local Emergency Management. Environmental Management. Pp 489494

LIPI dan UNESCO,2006. Kajian kesiapsiagaan masyarakat dalan mengantisipasi bencana gempa bumi dan tsunami,LIPI, Jakarta

Masmuh.Abdullah, 2008. Komunikasi Organisasi Dalam Perspektif Teori dan Praktek, UPT Penerbitan UMM: Malang

McEntire,D.A.,\&Myers,A.(2004). Preparing Communities for Disasters: Issues and Processes for Government Readiness. 
Dwi Agustina, Kolaborasi Antara Aparatur Birokrasi Pemerintah Daerah Istimewa ...

Disaster Prevention and

Management,13(2). Pp.140-152

Michael, Bruce, Setiawan B dan Rahmi,D.H. 2000.Pengelolaan Sumber Daya Alam dan Lingkungan, Gadjah Mada University Press, Yogyakarta.

Mileti, D. S (1999). Disater by Design. Washington DC: Josepth Henry Press.

Moe,T.L., \& Pathranarakul,P.(2006). An Integrated Approach to Natural Disaster Management: Public Project Management and Its Critical Succes Factors. Disaster Prevention and Management, 15 (3), 396-413

Moe, T.L Gehbauer, F., Senitz,s., \& Mueller, M. (2007). Balanced Scorecard for Natural Disaster Management Project. Disaster Prevention and Management, 16 (5), 785-806

Moleong.Lexi J. 2005 .Metodologi Penelitian Kulitatif. PT.Remaja

Rosdakarya:Bandung

Locke, L., Spirduso, W. W., \& Silverman, S. (2000). Research proposals that work. 4th Edition. New York: Sage Publishing Co.

Pratikno. 2008. Manajemen Jaringan Dalam Perspektif Strukturasi . Jurnal Kebijakan dan Administrasi Publik Volume 12, Nomor 1 ( Mei 2008 ). Yogyakarta : MAP UGM.

Perry, R.W., \& LIndell,M.K. (2003). Preparedness for Emergency Response: Guidelines for the Emergency Planning Process. Disasters, 27(4), pp.336-350

Perry, M. (2007) Natural Disaster Management Planning: A Studi of Logistics Managers Responding to the Tsunami. International Journal og Physical Distribution and logistics Management, Nol.37 No.5, pp. 409-433

Robbins,P.Stephen. and timothy A.Judge, 2009, Organizational Behavior, $13^{\text {th }}$ Edition, Pearson Education, Inc., Upper Saddle River, New Jersey, PP.209-586

Shaluf,I.M.(2008). Technologival Disaster Stages and Management. Disaster Prevention and Management.17 (1),pp.114-126

Sink, D.W. (1998). “Interorganizational
Collaboration”, dalam Shafaritz,J.M. (Ed.), The Encyclopedia of Public Policy and Administration. Boulder, CO: Westview

Stake, R. (1995). The art of case study research. Thousand Oaks, CA: Sage pp. 49-68). Sutara, Agus Ardianto, 2001. Atasi Konflik Etnis, Global Pustaka, Yogyakarta

Tingsanchali, T. (2005). Tsunami Attacks and Disaster Management. Paper presented at the Presentation of Findings by AIT Team of Expert on Tsunami Affected Areas in the South of Thailand.

Turner, J.R., \& Muller (2004). Communication and Co-Operation on Projects Between the Poject.Between Owner as Principal and the Project Manager as Agent. European Management Journal of Institutional and Theorical Economics, Vol 22 No.3, pp. $327-336$

Wolensky, R.P \& Wolensky, K.C. (1990). Local Government's Problem with Disaster Management: A literature Review and Structural Analysis. Policy Studies Review ,9(4), 703725 Wyner, A.J., \& Mann, D.E. (1983). Seismic Safety Policy In California: Local Governments and Earthquakes. Santa Barbara: Departurtement of political Science, University of California.

Quarentelli, E. L. (1997). Ten Criteria for Evaluating the Management of Community Disasters. Disaters, 21(1) pp.39-56

Undang-Undang, Peraturan Pemerintah, Peraturan Daerah dan Dokumen :

UU 24 tahun 2007 tentang penanggulangan bencana

Peraturan Presiden No.8 Tahun 2008 menyebutkan bahwa Unsur Pelaksana Penanggulangan Bencana

Peraturan Kepala BNPB 03 tahun 2012tentang Panduan Penilaian Kapasitas Daerah Dalam Penanggulangan Bencana 